\title{
Histone H1.2
}

National Cancer Institute

\section{Source}

National Cancer Institute. Histone H1.2. NCI Thesaurus. Code C162857.

Histone H1.2 (213 aa, $\sim 21 \mathrm{kDa}$ ) is encoded by the human H1-2 gene. This protein plays a role in nucleosome condensation. 